\title{
Pediatric residency program accreditation process by the Council for the Accreditation of Education Institutions
}

\author{
Juan B. Dartiguelongue, M.D. ., , Alfredo Eymann, M.D. ${ }^{b, c}$, María P. Molina, M.D. ${ }^{d, e}$,
} Horacio Yulitta, M.D. ${ }^{e, f}$ and Luis Urrutia, M.D. ${ }^{8}$

a. Hospital de Niños Ricardo Gutiérrez, Autonomous City of Buenos Aires, Argentina.

b. Department of Pediatrics, School of Medicine, Universidad de Buenos Aires, Argentina. Office at Hospital de Niños Ricardo Gutiérrez.

c. Hospital Italiano de Buenos Aires, Autonomous City of Buenos Aires, Argentina.

d. Hospital General de Agudos José M. Penna, Autonomous City of Buenos Aires, Argentina.

e. General Office for Teaching and Training, Autonomous City of Buenos Aires, Argentina.

f. Hospital Alemán, Autonomous City of Buenos Aires, Argentina.

g. Hospital de Pediatría SAMIC Prof. Dr. Juan P. Garrahan, Autonomous City of Buenos Aires, Argentina.

E-mail address:

Juan B. Dartiguelongue, M.D.:

jbdartiguelongue@

hotmail.com

Funding:

None.

Conflict of interest:

None.

Received: 10-19-2019

Accepted: 12-26-2019

\begin{abstract}
Introduction. Postgraduate medical education as part of a residency system is the best model for specialist training. The accreditation of residency programs entails a harmonization and standardization process. It defines a common and reproducible basis to ensure high-quality training and universal curricular guidelines. Objective. To describe the pediatric residency program accreditation process by the Council for the Accreditation of Education Institutions between January 2011 and July 2017.

Methods. The accreditation process was developed according to a reference framework that defined 6 domains and 28 items. Based on compliance, 3 accreditation categories were established. The analysis of accredited residency programs was categorized into 3 geographic regions: province of Buenos Aires, Autonomous City of Buenos Aires (CABA), and other regions. Each analyzed item was dichotomized into noncompliance and partial or total compliance. Categorical outcome measures were expressed in absolute numbers and percentage.

Results. Ninety-four pediatricresidency programs were assessed: $34(36 \%)$ corresponded to the province of Buenos Aires; $25(27 \%)$, to CABA; and $35(37 \%)$, to other regions. In total, $79(85 \%)$ were in the public sector. The maximum accreditation category was achieved by $35(37 \%)$. Four (4\%) were not accredited. Compliance for most items corresponding to the 6 domains was over $80 \%$. Conclusion. Most assessed residency programs were accredited and complied with the reference standards.

Key words: pediatrics, internship and residency programs, medical education, accreditation.
\end{abstract}

http: / / dx.doi.org/ 10.5546/ aap.2020.eng.245

To cite: Dartiguelongue JB, Eymann A, Molina MP, Yulitta H, Urrutia L. Pediatric residency program accreditation process by the Council for the Accreditation of Education Institutions. Arch Argent Pediatr 2020;118(4):245-251.

\section{INTRODUCTION \\ Reference framework}

In Argentina, newly graduated physicians may continue their training by specializing in a medical field or by specializing in teaching or research. Sometimes, they undertake all or some of these activities at the same time.

There are currently different ways to become certified in a medical specialty: 1) completing a residency program; 2) obtaining a postgraduate university degree that certifies a physician as a specialist (many times simultaneously with the residency program); 3) accrediting five years of training in a specialty service and passing an exam; 4) certifying competency before a scientific society registered at the Ministry of Health $(\mathrm{MoH}) ;$ and 5) obtaining the degree of university professor in a specialtyrelated subject. ${ }^{1,2}$

There is consensus that postgraduate education in the setting of a residency program system, as an instance of systematic and unsystematic learning together with on-service training, is the best model for medical specialty training. ${ }^{3}$ In Argentina, all graduated physicians have the chance to access the residency program system. However, since completing a residency program is not a deontological requirement to practice medicine, approximately half of graduated physicians decide to do it. Admission takes place through public or private tenders with different selection stages. ${ }^{4,5}$

Based on the official surveys available at present, approximately $70 \%$ of residency positions depend on state-run institutions at all levels 
(national, provincial, and municipal); $9 \%$, on universities; and the remaining $21 \%$, on private institutions. ${ }^{6,7}$ Although there is no consolidated, complete, and official registration of all the Argentine institutions where pediatricians can be trained, the Argentine Society of Pediatrics (Sociedad Argentina de Pediatría, SAP) has recently conducted, through an institutional research grant, a national survey on pediatric residency programs and has developed a complete registry of 188 pediatric training institutions.

Such higher education systems imply a complex interrelation among the hospitals, the university, the State, medical associations, scientific societies, and the civil society. As the responsible party for public investment in human capital development, the State plays, in this context, a key role in the assessment and accreditation of education institutions. Such phenomenon is precisely the result of the need to demonstrate the veracity or authenticity of the training process as well as to ensure that all training stages comply with reference standards. ${ }^{7}$

These processes were made official more than 20 years ago in countries like the United States of America and England so that, in addition to validating and justifying public investment in human resource education, they could deal with international economic competition, enhance postgraduate training, and favor the development of new technologies. ${ }^{7}$ The processes had to be necessarily reliable and implied designing a reproducible accreditation model that could be implemented by different institutions from different countries in this global context. One of the objectives of accreditation is to promote highquality education institutions to ensure health care providers receive a solid training aimed at improving population health. ${ }^{2,45,8}$

\section{THE SITUATION IN ARGENTINA}

Medical residency programs in Argentina were encouraged by Tiburcio Padilla, M.D., in 1944 through the creation of the first resident positions in the setting of the Chair of Semiology of Hospital de Clínicas José de San Martín. However, only towards the end of the 1950s, residency programs started to have a dynamic structure similar to what is known nowadays.

In 1957, Juan P. Garrahan, M.D., started the pediatric residency program in our country at Hospital de Clínicas, which corresponded to Universidad de Buenos Aires. One year later, Carlos Gianantonio, M.D., created the first organized and systematic residency program at Hospital de Niños Ricardo Gutiérrez. Since then and over the years, education institutions have multiplied across all Argentine regions.

The first attempt to assess education systems in Argentina took place in 1967, when the $\mathrm{MoH}$ created the National Medical Residency Council (Consejo Nacional de Residentado Médico, CONAREME) and designated it as the residency program standardization and assessment body. For political reasons, the CONAREME stopped working in 1973, so the accreditation process for education institutions was interrupted. ${ }^{9}$

In 1995, by means of the Higher Education Law, the State created the National Commission for University Assessment and Accreditation (Comisión Nacional de Evaluación y Acreditación Universitaria, CONEAU) in order to warrant and improve the quality of university academic training. ${ }^{10}$ According to this law, accreditation was mandatory for all university specialist degrees and, in accordance with the Regulatory Decree of Law no. 499/96 (section 7), it was established as an essential condition for the official recognition of degrees and their subsequent national validation by the Ministry of Education.

In relation to medical residency programs, including a residency in the accreditation system is voluntary, except for positions funded by the $\mathrm{MoH}$, for which accreditation is mandatory. In 1997, the SAP established an optional accreditation process for education institutions through its Subcommittee of Residency Program Accreditation. This mechanism allowed to define education standards, monitor compliance with the program and the different stages of resident learning and assessment. In turn, it allowed to assess the strengths and weaknesses of the different residency programs so as to improve specialist training. ${ }^{11,12}$

In 2006, the MoH (through Resolution no. 450/2006) created the National System for the Accreditation of Health Care Residency Programs (Sistema Nacional de Acreditación de Residencias del Equipo de Salud, SNARES) and the Integrated Registry for Assessment Bodies. ${ }^{4}$ Through its regulations, the SAP became an assessment body and was formally invited to participate in 2009.

In this context, the $\mathrm{MoH}$ created the Commission on Pediatrics, made up of representatives from universities, scientific and academic societies, professional associations, and members of national or jurisdictional programs 
related to pediatrics. The objective of this Commission was to develop a national reference framework for the training of pediatric specialists, which was formally presented in December $2010 .^{8}$ In 2011, the SAP created the Council for the Accreditation of Education Institutions (Consejo de Acreditación de Espacios de Formación, CAEF) to warrant the accreditation process.

Since then, the accreditation of pediatric residency programs, implemented by the $\mathrm{MoH}$ through the SAP, involved a harmonization and standardization process to establish the minimum requirements for pediatric training. It defined a common and reproducible basis to ensure high-quality training and develop universal curricular guidelines. To meet this objective, the CAEF, made up by a group of pediatric specialists and sub-specialists experienced in assessment and accreditation processes, was set to ensure, at every instance, the assessment of the development of education proposals (both theoretical and practical), learning follow-up and assessment, adequately diverse and sufficient cases offered by the different training scenarios (to warrant skill acquisition), faculty composition and background, and material conditions where learning scenarios were developed.

There is a report of a study that described the results of the assessment and accreditation process of 37 cardiology residency programs in Argentina. ${ }^{13}$ However, to date, no studies have been published that described the pediatric residency program accreditation process.

\section{OBJECTIVE}

To describe the pediatric residency program accreditation process by the CAEF between January 2011 and July 2017.

\section{POPULATION AND METHODS}

This was a cross-sectional study. Accreditation was defined as the systematic, independent, and documented process to recognize the qualification of a facility or service as a teaching facility or unit for the training of pediatric specialists in accordance with certain requirements or standards, including but not limited to, the minimum requirements in relation to human and physical resources, health care activities, teaching and research activities, and health care quality.

The accreditation process was developed as follows: 1) voluntary accreditation application before the MoH and the SAP; 2) document submission (standardized self-assessment and program), visit by 2 CAEF members (on-site visit, interview with the authorities and faculty, interview with residents); 3) development of a consensual team report, based on the assessment model to categorize residency programs, which defined accreditation based on 4 categories: A) 4 to 5 years; B) 3 years; C) 2 years; and not accredited.

According to the reference framework for accreditation, 6 domains and 28 items were defined:

1. Minimum hiring requirements: training scholarship with social security; 20 to 40 weekly outpatient visits per resident; 6 to 8 beds assigned to each resident; opportunity to practice and perform procedures.

2. Characteristics of the training offer: at least 1 staff physician certified in the specialty working from 8 a.m. to 5 p.m.; at least 18 hospitalization beds; access to diagnostic services (clinical and microbiological laboratory and imaging tests); access to consultations with specialists; interdisciplinary health care team (nursing, social work, mental health); library and/or access to a database; classroom and lodging conditions (bedroom, bathroom, food); practice and procedure recording.

3. Working hours and on-duty system: program duration of 3 or more years; maximum stay of 80 hours per week, including on-duty hours; maximum of 2 on-duty shifts per week, at least 24 hours apart; and effective rest after onduty shift of 6 consecutive hours in an intra- or extra-institutional setting.

4. Mandatory rotations: Neonatology, Pediatric Intensive Care Unit, Health Centers, and Department of Adolescence or outpatient office for adolescents.

5. Academic activities: 5 hours per week for theoretical activities (lessons, bibliographic search, case discussion, report writing, simulations, workshops, etc.); at least 1 clinical grand round per week; participation in research studies.

6. Assessment system: annual, comprehensive, theoretical-practical exam; theoretical-practical exam after the rotation, and final residency theoretical-practical exam.

Analysis was categorized into 3 geographic regions: province of Buenos Aires, Autonomous City of Buenos Aires (CABA), and other regions. Each item was dichotomized into non-compliance and partial or total compliance. Categorical 
outcome measures were expressed in absolute numbers and percentage.

\section{RESULTS}

Ninety-four pediatric residency programs were assessed. They were distributed in the province of Buenos Aires (34), CABA (25), and other regions (35). Figure 1 describes the geographic distribution of residency programs. Table 1 provides the details of residency program distribution into public or private and accreditation categories by region. Compliance with the 6 defined domains by region is described in Table 2.

\section{DISCUSSION}

In the study period, the CAEF, together with the $\mathrm{MoH}$, successfully assessed 94 pediatric residency programs in 20 Argentine provinces. Most education institutions ( $>60 \%$ ) were located in $\mathrm{CABA}$ and the province of Buenos Aires. Although both regions accounted for $40 \%$ of the Argentine population, this showed that resource distribution was centralized and rather inequitable.

Practice and procedure recording was adequate in CABA and lower in the residency programs carried out in the province of Buenos Aires and other regions. This item was also observed by other accreditation bodies, such as the CONEAU.

The minimum hiring requirements and the characteristics of the training offer of assessed residency programs met most of the required standards. The availability of libraries or access to educational materials was partial in the 3 assessed regions, especially in the "other regions" category. This is probably due to the limited resources available for the subscription to international journals or databases, as well as for the procurement of study material.

Both the program duration and the estimated working hours were adequate for all assessed residency programs. The on-duty system was adequate for the reference standard, except in relation to rest after on-duty shift, which showed a greater compliance in CABA than in

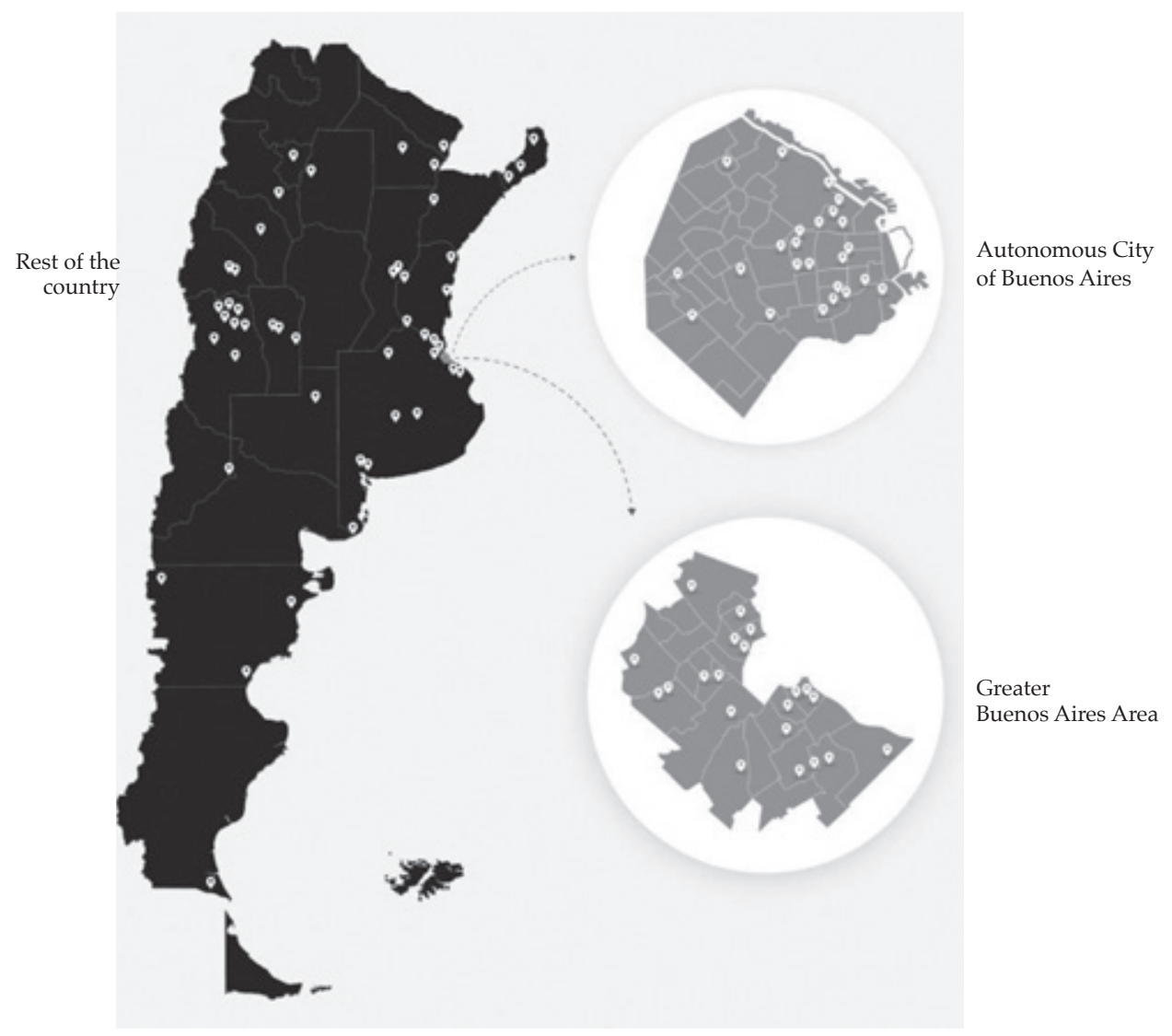


the rest of the country. This aspect was a relevant outcome measure related to two of the current problems faced by medical professionals: burnout syndrome and medical errors. Both are worsened by (psychological and physical) stress and the lack of rest. ${ }^{14-16}$
CABA residency programs are currently regulated by Law no. 4702, passed in 2013, which limits the maximum number of on-duty shifts per week and warrants rest after an on-duty shift. In addition, section 10 of $\mathrm{MoH}$ Resolution no. 1993/2015 determines the maximum number

TABLE 1. Characteristics of accredited residency programs by accreditation category and management type by region

\begin{tabular}{llcccc}
\hline & & $\begin{array}{c}\text { Province of Buenos Aires } \\
(\mathbf{n}=\mathbf{3 4})\end{array}$ & $\begin{array}{c}\text { CABA }^{*} \\
(\mathbf{n}=\mathbf{2 5})\end{array}$ & $\begin{array}{c}\text { Other regions } \\
(\mathbf{n}=\mathbf{3 5})\end{array}$ & Total \\
\hline Accreditation category & 4-5 years & 9 & 13 & 13 & 35 \\
& 3 years & 16 & 9 & 12 & 37 \\
& 2 years & 7 & 3 & 8 & 18 \\
\multirow{5}{*}{ Type of management } & Not accredited & 2 & 0 & 2 & 4 \\
& Public & 32 & 9 & 4 & 79 \\
& Private & 2 & 16 & 31 & 15 \\
\hline
\end{tabular}

* Autonomous City of Buenos Aires.

TABLE 2. Compliance with conditions by region (\%)

\begin{tabular}{|c|c|c|c|}
\hline & $\begin{array}{l}\text { Province of Buenos Aires } \\
\qquad(\mathrm{n}=34)\end{array}$ & $\begin{array}{l}\mathrm{CABA}^{*} \\
(\mathrm{n}=25)\end{array}$ & $\begin{array}{l}\text { Other regions } \\
\quad(\mathrm{n}=35)\end{array}$ \\
\hline \multicolumn{4}{|c|}{ Compliance with hiring requirements and training opportunities } \\
\hline No. of beds assigned to residents & 97.1 & 100 & 97.1 \\
\hline Outpatient visits & 100 & 100 & 100 \\
\hline Practice and procedure recording & 47 & 84 & 40 \\
\hline Contract & 97.1 & 100 & 100 \\
\hline \multicolumn{4}{|l|}{ Compliance with training conditions } \\
\hline Staff physicians & 100 & 100 & 100 \\
\hline No. of beds & 100 & 100 & 97.1 \\
\hline Diagnostic services & 100 & 100 & 100 \\
\hline Interdisciplinary team & 100 & 100 & 97.1 \\
\hline Specialist consultation & 100 & 100 & 97.1 \\
\hline Classroom & 94.1 & 100 & 88.6 \\
\hline Library & 85.3 & 76 & 62.9 \\
\hline Lodging & 97.1 & 100 & 100 \\
\hline \multicolumn{4}{|c|}{ Compliance with working hours and on-duty system } \\
\hline Program duration & 100 & 100 & 100 \\
\hline Working hours & 97 & 100 & 100 \\
\hline On-duty shifts & 97 & 100 & 91.4 \\
\hline Rest after on-duty shift & 50 & 92 & 20 \\
\hline \multicolumn{4}{|c|}{ Compliance with mandatory rotations by region } \\
\hline PICU & 100 & 100 & 91.4 \\
\hline Neonatology & 100 & 100 & 94.3 \\
\hline Health center & 85.3 & 96 & 88.6 \\
\hline Adolescence & 35.3 & 80 & 22.9 \\
\hline \multicolumn{4}{|c|}{ Compliance with academic activities by region } \\
\hline Grand rounds & 97.1 & 96 & 85.7 \\
\hline Theoretical activities & 100 & 96 & 94.3 \\
\hline Research & 91.2 & 72 & 71.4 \\
\hline \multicolumn{4}{|c|}{ Compliance with resident assessment by region } \\
\hline After the rotation & 91.2 & 100 & 91.2 \\
\hline Annually & 97.1 & 96 & 97.1 \\
\hline At the end of the residency & 79.4 & 95.8 & 85.7 \\
\hline
\end{tabular}

* Autonomous City of Buenos Aires; PICU: pediatric intensive care unit. 
of weekly on-duty shifts and mandatory rest after the shift. This is a mandatory resolution for national residency programs and defines the reference framework for accreditation by the $\mathrm{MoH}$ in relation to this domain.

The rotation system conformed to the rotation standard for Neonatology, Intensive care, and Outpatient care, but not for the Adolescence rotation. Compliance was $80 \%$ in CABA, but it was lower in the rest of the regions. This is probably related to the fact that, although Adolescence was a long-standing pediatric subspecialty, few education institutions offered it in our country and it was not recognized as a subspecialty by the $\mathrm{MoH}$.

Academic activities, including grand rounds and theoretical activities, conformed to the reference standard for all assessed regions. In relation to research activities, they were less common in CABA and other regions than in the province of Buenos Aires. The authorities of all assessed programs stated their intention to comply with this standard. However, since the main activities carried out as part of the residency involved care and teaching duties, research production translated mostly into case reporting.

The assessment system, both the annual exam and an exam at the end of each mandatory rotation, was adequate in relation to the reference framework in all assessed regions. A greater compliance was observed in relation to the exam at the end of the residency program in $\mathrm{CABA}$ than in the rest of the regions. Most exams corresponded to multiple-choice tests, resolution of clinical situations, and performance assessments. An objective and structured clinical exam was used only as an assessment tool in CABA for first-year residents as a training strategy.

Since including a residency program in the accreditation system is voluntary (except for residency positions funded by the $\mathrm{MoH}$, for which it is mandatory), in all probability, the analysis of residency programs included in this study corresponded mostly to those whose training programs have a better educational reputation; therefore, based on their adequate performance, they may have applied for accreditation voluntarily. The situation of the other 94 residency programs of the 188 total pediatric residency programs surveyed in Argentina to date remains to be analyzed.

The regional asymmetries observed here may be explained by the fact that the residency system has been in force in CABA and the province of Buenos Aires for a longer time. These regions have probably had more chances to improve their training standards thanks to the visits by accreditation system representatives and their reflection on their programs.

The responsibility of promoting the development of high-quality programs to train health care providers aimed at improving population health is common to those in charge of residency programs, scientific societies, and provincial and national State agencies. The accreditation process is critical to warrant the quality of education institutions. A good example of this is the performance in the SAP's pediatric certification exam. The probability of passing this exam was almost three times higher among candidates who had taken part in training programs offered by those institutions that displayed the maximum accreditation category. ${ }^{17}$

\section{CONCLUSION}

Most assessed residency programs (96\%) had been accredited and complied with the reference standards proposed by the CAEF and the $\mathrm{MoH}^{\prime} \mathrm{s}$ Board on Human Capital.

\section{REFERENCES}

1. Ley 23873. Arte de curar. Modificase la Ley 17132 Ejercicio de la medicina, odontología y actividades auxiliares. Poder Legislativo Nacional. Buenos Aires, Argentina; 24 de octubre de 1990.

2. Borrell Bentz RM. La educación médica de posgrado en Argentina: el desafío de una nueva práctica educativa. Buenos Aires: OPS; 2005.

3. Centeno A, Campos S. La educación médica en argentina. FEM. 2017; 20(6):265-71.

4. Ministerio deSalud.Dirección Nacional de Capital Humano y Salud Ocupacional. Observatorio de Recursos Humanos en Salud. Argentina; 2015. [Accessed on: December 27th, 2019]. Available at: https: / / www.argentina.gob.ar/salud/ observatorio/publicaciones.

5. Duré I, Daverio D, Dursi C. Planificación y gestión del sistema nacional de residencias en Argentina. Observatorio de Recursos Humanos en Salud. Ministerio de Salud. Argentina; 2013. [Accessed on: December 27th, 2019$]$ ] Available at: https://www.argentina.gob.ar/sites / default / files / dure-daverio-dursi-observatrhus_planif_ gestion_sistresid-2013.pdf.

6. Duré I. El sistema nacional de acreditación de residencias. Avances y desafíos. Presentación en la ACAP. Argentina; 2014. [Accessed on: December 27 ${ }^{\text {th }}$, 2019]. Available at: http: / / iah.salud.gob.ar/ doc/Documento5.pdf.

7. Duré I, Attme de Ceballos I, Cadile M, Calbi M, et al. Procesos de Acreditación de la Formación de Posgrado de Carreras de Salud en Argentina. Hacia la consolidación de un sistema articulado. [Accessed on: December 27 ${ }^{\text {th }}$, 2019]. Available at: https://www.argentina.gob.ar/ sites / default / files / acreditacion-de-formacion-posgradocarreras-salud-argentina.pdf. 
8. Ministerio de Salud. Marco de referencia para la formación en residencias médicas. Especialidad Pediatría.2010. [Accessed on: December $\left.27^{\text {th }}, 2019\right]$. Available at: https: / / www.argentina.gob.ar/sites/default/ files/pediatria.pdf.

9. Ministerio de Salud de la Nación. Documento Marco de Residencias del Equipo de Salud. 2011. [Accessed on: December $\left.27^{\text {th }}, 2019\right]$. Available at: https: / / www.argentina. gob.ar/sites/default/files/documento_marco_residencias_ ok.pdf.

10. Ley $\mathrm{N}^{\mathrm{o}}$ 24521. Educación Superior. InfoLEG. Buenos Aires, Argentina; 7 de agosto de 1995.

11. Subcomisión de Acreditación de Resicidencias. Evaluación del primer ciclo de acreditación de residencias. Arch Argent Pediatr. 2001; 99(6):542-4.

12. Subcomisión de Acreditación de Residencias delaSociedad Argentina dePediatría. Enbúsqueda de estándares mínimos para acceder a la acreditación de una residencia en clínica pediátrica. Arch Argent Pediatr. 2004; 102(5):397-401.
13. Lobianco M, Galli A, Swieszkowski S, Kazelian L, et al. Evaluación y acreditación de residencias de cardiología. Años 2010-21017. Rev Argent Cardiol. 2019; 87:296-300.

14. IsHakWW,LedererS, MandiliC, NikraveshR, etal. Burnout During Residency Training: A Literature Review. J Grad Med Educ. 2009; 1(2):236-42.

15. Pereira-Lima K, LuoreiroSR. Burnout, anxiety, depression, and social skills in medical residents. Psychol Health Med. 2015; 20(3):353-62.

16. Bradley CK, Fischer MA, Walsh KE. Trends in medical error education: are we failing our residents? Acad Pediatr. 2013; 13(1):59-64.

17. Ferrero F, Yulitta H, Molina MP, Valli R. Resultado del examen de certificación de médico pediatra de la Sociedad Argentina de Pediatría, años 2001-2010. Arch Argent Pediatr. 2011; 109(4):321-5. 